\title{
How much Schopenhauer is there really in Wagner?
}

\author{
Alessandro Pinzani \\ Universidade Federal de Santa Catarina - UFSC - Florianópolis
}

\begin{abstract}
The paper aims at analyzing some Wagnerian figures in order to show that the influence of Schopenhauer's philosophy on Wagner is not as strong as commonly held - at least not in his operas. The figures that shall be considered are: Wotan and Brünnhilde, Tristan and Isolde, and finally Parsifal, who appears to be the only Schopenhauerian character of all.

Keywords: Wagner. Schopenhauer. Opera
\end{abstract}

It is not my intention in this paper to speak generically of the influence of Schopenhauer's philosophy on Wagner. ${ }^{1}$ I shall rather try to analyze five Wagnerian figures in order to show that the current opinion on Schopenhauer's influence on his works should be at least partially revised. While Schopenhauer's thought undoubtedly impressed Wagner very much, this influence should be sought rather in some theoretical aspects, that is, with regard to the role Wagner assigns to art in general and to music in particular, and maybe in some musical aspects. This influence seems to be weaker precisely with regard to the dramaturgical aspect, to the librettos, in which we would expect to find it at its strongest, but in which on the contrary we are confronted with figures and situations that are rather at odds with Schopenhauer's thought.

The figures I shall consider are Wotan and Brünnhilde, Tristan and Isolde, and finally Parsifal. The choice is not arbitrary, but is in a sense an obligatory one, since Wagner himself connects these figures to Schopenhauer's philosophy. But first, let me reconstruct briefly the circumstances under which Wagner fell under the spell of Schopenhauer.

In 1854 Wagner finishes with the composition of the musical score of Walküre. In the fall of that year he reads for the first time The World as Will and Representation. In the summer of 1855 he claims to have read the book already

\footnotetext{
${ }^{1}$ Nor shall I deal with the question of how it is possible that Wagner was so profoundly impressed by Schopenhauer's idea of compassion and at the same time wrote some of the most rabid and heinous antiSemitic writings of World history. By all his artistic merits and artistic integrity, Wagner did never act coherently from a non-artistic point of view. In his typical self-indulgence, he would have probably considered as a mark of intellectual independence what strikes us as plain incoherence and hideous racism (since his anti-Semitic views were based on racial theories, not on the traditional Christian resentment against the so-called "murderers of God").
} 
four times and in fact he shall read it over and over since that moment. The diaries of his wife Cosima testify of this steady, systematical and repeated study of Schopenhauer's masterwork. At first she notes when she and her husband would have read Kant and Schopenhauer at night. After a while, she notes rather the uncommon event of not having read Schopenhauer ("Heute kein S."). It seems that this enthusiasm was not reciprocated by the philosopher. He liked the libretto of the Ring, although he wondered why the composer had sent it to him without a presentation letter; he even held Wagner for a decent, even if not a good poet, but apparently he did not like Wagner's music. This should come as no surprise, since the examples of opera he mentions with appreciation in his book are Mozart's Don Giovanni and Bellini's Norma, which are quite far from Wagnerian artistic forms and ideals. Anyway, Wagner became a life-long adept of Schopenhauer: he gave his book as a present to friends and simple acquaintances and always wanted to discuss it with them. Some reacted with irritation or rage, since they considered this infatuation for Schopenhauer's apolitical, pessimistic thought to be treason to Wagner's early social ideals. This idea can be found in several authors (notably Nietzsche and G. B. Shaw) who think that the revolutionary Wagner of the Forties became in the Fifties a reactionary, going over from an optimistic political position and from a strong will of artistic change to a radical pessimism and, in Parsifal, to an ascetic renunciation towards life. We shall consider later whether this criticism is correct with regard to Parsifal.

On the other side, if we consider Wagner's theoretical writings before his encounter with Schopenhauer, we can find many common points with regard to the priority assigned to music over the other arts. This lead Edouard Sans, who analyzed extensively the relationship between the composer and the philosopher, to write that Wagner "was intimately ready to get from the philosopher the validation of his deepest convictions. Schopenhauer will preach to the choir" (SANS 1969, p. 263). From this point of view, the writing on Beethoven from 1870, the most "Schopenhauerian" among Wagner's writings, could be seen alternatively either as the most accomplished expression of the "true" Wagner, or as a mere repetition of old ideas in new form, or as a complete change in the composer's theoretical stance. The querelle is far from being solved, but it will not matter here (for an analysis of the different readings see COOKE 1979, MAGEE 1988 and NATTIEZ 1997). 
Wagner himself admitted that in reading Schopenhauer he recognized in the idea of the renunciation to will the very same idea that moved all his main characters: the Flying Dutchman, whose only aspiration is to be freed from his immortality, from the eternal cycle of seven years and a day to which he is condemned; Tannhäuser, who in fact seeks in sex only a way of escaping from the world; even Lohengrin, although it is not so easy to understand what Wagner is referring to. In any case, he claims that thanks to his reading of The World as Will and Representation he became conscious of things he had just sensed before, without grasping them fully. He even wrote in a letter that "only now I got to understand my Wotan”. In his highly unreliable, but nevertheless fundamental autobiography Wagner writes that he found in Schopenhauer all what he had already expressed in literary and metaphorical form in the Ring libretto. This is a relevant claim and we should take it seriously.

What was Wagner's original aim when he started working on the Ring? Of course he had an aesthetical intention, namely to complete an artwork that corresponded to the ideals he defended in his theoretical writings like The Artwork of the Future or Opera and Drama. But we are not interested in the aesthetical or musical aspects, rather in the philosophical, ideal or even ideological ones in the librettos. Wagner's original intention when he started working on the libretto was notably to describe a world characterized by the lack of love and by injustice (in that time the composer stand under the influence of Feuerbach, as it is wellknown). This is symbolized by the act through which at the beginning of the Ring Alberich curses love and steals the Rhine gold - an act that, however, just duplicates the act through which Wotan had ripped out a branch of the cosmic ash in order to build a shaft for his spear. The redemption from this unjust, loveless world should happen through an extraordinary couple, Brünnhilde and Siegfried, which should come about thank the breaking-off of social conventions (Siegfried is the son of two siblings: Siegmund and Sieglinde) and of the dominant social order (Brünnhilde is a rebel against the father and, indirectly, against Fricka, who stand both guarantor for this order: Wotan guaranteeing pacts and contracts, Fricka guaranteeing the familiar ties and the mores, the Sitten). While working at the libretto, however, dramaturgical reasons lead Wagner to change radically his project. Far from redeeming the world through their love, Siegfried and Brünnhilde 
end up drifting apart irreconcilably. ${ }^{2}$ When, at the end of the Ring, Brünnhilde throws the ring back into the Rhine, Siegfried has already died thanks to her plotting with Hagen and the Walhalla is burning. Her redemptive act is very different from the one initially imagined by Wagner: apparently we are not faced with redemption through the love of a couple, rather with expiation through havoc and destruction.

To this change in the story corresponds a radical change in one of the Ring's main characters, namely, Wotan. At the beginning of Rheingold we find an extremely self-confident Wotan. At the end of this opera, after Erda has warned him to let the ring go and has preannounced the twilight of the gods, Wotan loses shortly his self-confidence, but he thinks immediately of a plan to get back the ring and prevent the fall of Walhalla, as his words to Fricka let guess. At the beginning of Walküre he is still convinced that his plan is going to work: he will use Siegmund to vanquish Fafner and get back the ring. His confidence is destroyed by Fricka in a dialogue that represents the central moment of the Ring along with the following scene with Brünnhilde. His wife shows him the futility of his effort: far from acting freely, Siegmund is just a tool in Wotan's hands, a puppet executing his order, while he, the god, is the real actor. Wotan is forced to acknowledge that Fricka is right and this revelation devastates him. Therefore, in the following dialogue with his daughter he expresses all his discouragement and despair, coming so far as to wish that Alberich might recover the ring. This is not even pessimism: it is plain nihilism, if one considers the dwarf's intentions. In one of the musically more intense pages of the whole Ring Wotan cries:

"I give up my work.

Only one thing I want now:

the end,

the end!"

However, on several occasions Wotan shall admit that this decision of wanting the end was taken in a moment of despair and rage and that he did not renounce definitively his plans. In Siegfried, Wotan, who now calls himself Wanderer (but

\footnotetext{
${ }^{2}$ The hero, under the spell of Hagen's magic potion, promises to Günther to conquer Brünnhilde for him as a bride in order to get in exchange Gutrune's hand. When Brünnhilde sees her husband at the side of his new bride, she swears revenge and reveals to Hagen where Siegfried's weak spot lies: in his back. Therefore Hagen is able to kill Siegfried. When she learns from Gutrune that Siegfried was under the spell of the magic potion, however, Brünnhilde goes back to her initial love, climbs up the pyre where his lover's corpse lies, starts the fire that shall destroy Walhalla and throw the ring in the Rhine.
} 
whom the two Nibelungs and Erda recognize at once when they meet him), seems still to entertain the hope of preventing at least that the ring falls in the hands of his arch-enemy Alberich. This is not tantamount to saying that Wotan does not want the end anymore. Rather, he wants this ending to be his ending, that is, an ending according to his plans (see KITCHER \& SCHACHT 2004). The fact that he now wants the end of everything is no longer the result of a mood of despair, but of an explicit choice, as Wotan explains to Erda in their dramatic dialogue. I wonder whether this makes a Schopenhauerian character out of him. First of all, the intensity with which Wotan claims to desire the end has nothing of the complete renunciation to one's will that according to Schopenhauer should represent our final ideal; furthermore, notwithstanding his desiring the end, Wotan does not want any end whatsoever, but still pursues an ambitious plan: he wants to give back somehow the ring to the Rhine daughters. For this reason, after his encounter with Siegfried, shocked and appalled by the hero's arrogance and egoism, the god closes himself in an attitude of somber silence and bitter disappointment, as Waltraute tells Brünnhilde in Götterdämmerung. This is the first time that Brünnhilde is faced with the ring dilemma: on the one side it is the pawn of Siegfried's love, to which she does not want to renounce, understandably; on the other side the equilibrium broken by Alberich will be restored only when the ring will return to the Rhine, as Waltraute explains. But the valkyrie has not yet grasped this point and thinks only that all Waltraute wants is just to restore Wotan's peace of mind. Only at the end, after Siegfried having betrayed her, after having seen their love wretchedly fall apart because of human wickedness and corruption, Brünnhilde realizes that Waltraute was right, that the only way out is to give back the ring to the Rhine daughters. Returning the ring may not, however, be an unconscious act. This is the reason why the Rhine daughters reject the ring when Siegfried offers it to them in a typically thoughtless act. The hero does never realize what the ring really means; he would trade it now for carnal love. This is why the Rhine daughters cannot accept it - not for that reason. The ring was molded through an act of renunciation to love; now it has to be returned through an act of love, not of mere sexual desire. This act of love is that of Brünnhilde, who forgives Siegfried and decides to relieve Wotan from his somber anguish by returning the ring to the Rhine. This means however that the ending of the Ring is still inspired by Feuerbach: we have redemption through love, even if not through 
the love of a pair, but through the love of a wife for her husband and of a daughter for her father. This is no Schopenhauerian ending, nobody stops desiring or wanting anything. The interesting thing is that Wagner, after having read The World as Will and Representation, had foreseen precisely such a Schopenhauerian ending. He wrote for Brünnhilde's final monologue some lines in which the valkyrie shows a markedly Schopenhauerian attitude. These are the lines:

"From the land of desire I depart,

The land of illusion I flee for ever;

The open gates

Of eternal becoming

I close behind me:

To the desire-free, illusion-free

Holiest chosen land,

The goal of world wandering,

Redeemed from rebirth,

She who understands now departs.

The blessed end

Of all things eternal,

Do you know how I reached it?

Deepest suffering

Of grieving love

Opened my eyes:

I saw the world end." (quoted in COOKE 1979, p. 22 - My italics)

Of course Wagner decided not to use these lines and stuck by the original version, which is the one he set to music. The returning of the ring to the Rhine would have become a gesture marked by indifference, not by love. Indifference is not redemptive - not in the sense Wagner was thinking of: Brünnhilde redeems not just herself (as it would happen according to the Schopenhauerian lines), but also Siegfried, Wotan and, in a sense, the whole world. In the original and final version, she addresses the god with these words:

"Do I know now what is your will?

Everything, everything,

everything I know,

all is now clear to me!

ethic@-Florianópolis, v. 11, n. 2, p. 211 -226, julho de 2012. 
I hear your ravens

stirring too;

with dreaded desired tidings

I now send them both home.

Rest, rest now, o god!”

This final insight, which brings wisdom and illumination to her, makes her aware of the necessity of destroying the ring as a symbol of everything that is wretched in the world: lack of love, will to dominate, hatred, desire of power, violence, betrayal - in a word: all what destroyed the love of Brünnhilde and Siegfried as well as the one of Siegmund and Sieglinde.

In this sense the Ring is the story of a failure: the failure of Wotan's attempt to create a stable order and to impose his will to the world by force. As the Norns remind us in the prologue of Götterdämmerung, the history of the world starts precisely when Wotan rips off a branch of the cosmic ash in order to build his spear, which shall become the symbol of his power: history starts therefore with an act of violence on nature, with an act that breaks the original equilibrium. In the course of the Ring, Wotan realizes that a world arisen from violence and injustice (in the first place from his own violence and injustice) cannot be redeemed but by reestablishing somehow the status quo ante, i.e. by recreating the equilibrium between man and nature that Wotan himself had broken even before his alter ego Alberich would commit an act analogous in intention and effect by stealing the Rhine's gold. What Brünnhilde claims to "know now", at the end of the Ring, is precisely this: it is necessary that the ring goes back to the Rhine with a gesture of reparation, so that this world, resulting from disequilibrium, violence and desire of power, may die in the purifying flames of Loge, who, as the embodiment of fire, is an emblematic figure representing the primeval natural powers forced by Wotan to serve him, as Loge himself comments angrily in the finale of Rheingold. The new world will be inherited by the multitude of women and men that attends silently and terrified to the final catastrophe. They are no gods, they are no heroes: they are simple human beings without a name and without a face. Will they be able to build a different world, where law and order are not ground on an act of violence but on love? The message is clearly a Feuerbachian, not a Schopenhauerian one. 
Tristan und Isolde represents maybe the highest result of Wagnerian art. From the musical point of view it is certainly different from any other composition by Wagner and by composers of his time. The famous Tristan chord is probably directly inspired by Schopenhauer's vision of music. The philosopher writes that music raises expectations in its hearers and leads them to desire that its melody resolve itself in its tonic. If this does not happen, we feel frustrated, as if the melody had remained unfinished, interrupted. This is why Schopenhauer says that "music consists generally in a constant succession of chords more or less disquieting, i.e. of chords exciting desire, with chords more or less quieting and satisfying; just as the life of the heart (the will) is a constant succession of greater or lesser disquietude, through desire or fear, with composure in degrees just as varied" (WWR II, 456). In this context, Schopenhauer mentions musical suspension. This is given when what we thought to be the penultimate chord of a musical piece is not followed by the last chord and by the resolution on to a concord, but by another discord, by a chord that prolongs this resolution, creating an effect of surprise and desire, so that when the resolution finally comes the feeling of satisfaction is even bigger. In a sense one could claim that the whole Tristan and Isolde is just a single suspension, since the real resolution only occurs at the last chord of the opera. The Tristan chord with which the opera starts contains two dissonances and only one of them is resolved, while the resolution of the other is prolonged - and this goes on for the whole opera: every resolved chord is followed by an unresolved one, so that the hearer remains at the same time satisfied and unsatisfied and the suspense is maintained till the end (cf. MAGEE 2001, p. 206 ff.). Even tenser is the prelude to the third act of Parsifal, in which it is almost impossible to identify the tonic and every chord seems to be written in a different tonic, in an anticipation of atonality.

Tristan und Isolde is an opera in which almost nothing happens from the point of view of external events; however, the few events are momentous: in the first act Tristan and Isolde drink the potion; in the second act they are caught in the act by Marke, and Tristan lets himself get wounded by Melot; in the third act, the richest in action, Tristan dies in Isolde's arms, Kurwenal kills Melot and is killed on his part, Isolde dies. The libretto does not reach the philosophical sophistication of those of Meistersinger or of the Ring, even if in act II there are some interesting dialogues between the two main characters. Generally speaking, words are pushed 
in the background by music. But if there are not many external events, there is an endless richness of psychological events, while we are faced with the subtlest interior oscillations in the lovers' souls, which are exposed integrally to our eyes or - better - to our ears, since everything is music in this opera, included feelings and ideas. But which are these ideas? And why is this opera called "metaphysics as music" (MAGEE 2001, p. 205) or considered by many to be a thoroughly Schopenhauerian opera?

Usually, Schopenhauer's main influence on this opera is seen in the fact that Tristan und Isolde seems to be a perfect exemplification of the metaphysics of sexual love contained in the The World as Will and Representation. The main characters seem to coalesce in such a deep embrace that they cease to exist as individuals and become a single thing, as they sing during their almost mystical ecstasy in Act II. This ecstasy resembles very much the ecstasy attained during the sexual intercourse, in which it is possible to reach an intimate knowledge of the world's essence, of the will to live itself, according to Schopenhauer. On the other side, for the philosopher this knowledge represents just a necessary stage on the path toward the liberation of the individual from that very same will to live. This is apparently also Tristan and Isolde's attitude, since they speak of their will to annihilate their individuality in order to form a superior unity in death. But is it really so?

In order to understand what they really want, we should concentrate on a word, which they use frequently both as a verb and as a noun: Sehnen, which one could translate with "longing", but not in the sense of desiring something specific. It is a Schopenhauerian longing, in a sense. Tristan can be said to die out of longing, but at the same time it is this very longing that keeps him alive till his death (on Tristan's longing for death see ŽIŽEK \& DOLAR 2002, p. 103 ff.). When they are together, the two lovers feel for each other such a longing that makes it impossible that it be ever satisfied but through death - death that goes with their love from the very beginning, from the moment they drink together the love potion thinking it to be a mortal poison that will put an end to their forbidden, still unconfessed love; or from their first encounter, when Isolde finds Tristan mortally wounded after having killed Morold.

Most of Act II is a long dialogue in which the two express both this insatiable longing and their absolute refusal of the world. At the beginning of 
every act the world remains literally in the background, out of sight: in the sailor's melancholic song of Act I, in the hopefully resounding hunting horns of Act II, in the shepherd's sad song (almost a dirge) of Act III. The lovers perceive the world in a blurred form, through the mediation of their loyal fellows Brangäne and Kurwenal. They do not hear the hailing cries of welcome at the end of Act I (cries that come from the world outside the scene, concretely from the wings); they do not pay attention to Brangäne's warnings in Act II (warnings that also come from the wings) and they almost do not react to Marke's arrival; finally, in Act III Isolde does not react at all to Brangäne and Marke's calls. They are lost in a reality of their own, in which there is place only for their longing for annihilation and mutual coalescing - that mutual blending that for Schopenhauer is possible only through sex, but for our lovers (and for Wagner?) only through death.

What would Schopenhauer say of this longing for death - he, who condemned suicide when committed out of love's pain? Are our lovers longing for annihilation or rather for becoming one in death? On the one side, the concept of Sehnen refers to Schopenhauer's thought; on the other side, Tristan and Isolde never stop desiring each other in such a strong way that they die literally of desire. In Act II they proudly announce their plan:

"Thus would we die,

that together

ever one,

without end -

never waking -

never fearing -

namelessly

enveloped in love,

given up to ourselves

to live only for love!"

As a matter of fact, they try several times to reach this kind of union. First when they drink the potion thinking it to be a poison. They are already in love with each other, actually, but they are not willing to admit it and may not admit it, since their love is illicit. The potion is just a catalyst that lets their true feelings emerge and brings them to a state of ecstasy in which they forget the world and in which only the other exists - or better: only the incommensurate pleasure of their love exists: 
"You my only awareness, utmost rapture of love!" They are torn from this state by the hails of the sailors, by Brangäne and by an appalled and worried Kurwenal. In Act II their attempt to lose themselves in mutual fusion is interrupted by Brangäne's piercing scream and by Marke's arrival. In Act III Tristan dies in Isolde's arms before she might say or do anything but speaking out his name. The plan of dying together fails for a matter of seconds. Isolde tries to follow Tristan immediately, but she is hindered once again by Brangäne and Marke. Only in her second attempt she manages to put herself in a state of trance that leads her to death (at least according to Wagner: in Jean-Pierre Ponnelle's famous staging in Bayreuth she survives).

The time lapse between both deaths is not irrelevant, since it marks, as I said, the failure of the lovers' plan: they do not manage to die together out of love. Death is unavoidably an individual experience, like birth, as Schopenhauer pointed out. Through death the individual can get rid of his own individuality and disappear in the cosmic All, as Buddhism puts it, but not melt with another individual - which is precisely what Tristan and Isolde aim at. They do not want to disappear in the cosmic All; they want to abandon their individuality in order to form a super-individual, a unique being in which they are no longer Tristan and Isolde, as they sing in Act II, but just one, Tristolde, so to say. Wagner follows Schopenhauer only up to a point: the final redemption, the renunciation to one's will and individuality is replaced by the longing for a perfect melting with the other - a plan condemned to failure by the sheer impossibility of its realization. In his long monologue in Act III Tristan expresses his awareness of this impossibility by remarking that Isolde, however much she belongs to him and suffers with him, cannot suffer exactly what he is suffering in that moment. Pain, like death, is something unavoidably individual. Our lovers are always faced with the impossibility of overcoming the barrier that divides two individualities. Orgasm is just a way of breaching that barrier - and for that reason they want to make their orgasm (identified with night and darkness) eternal, as it appears in their invocation to night in Act II. The opposition of night and day, darkness and light can be also considered to be a reference to Schopenhauer: day and light represent the realm of appearance, of representation, while night and darkness stand for that obscure reality beyond Maya's veil, for Will (cf. SCRUTON 2004, p. 130). In 1868, in his notebook called Braunes Buch, Wagner lays down the 
following scheme, which makes clear how influenced he was by Schopenhauer and by Eastern philosophy:

"Truth $=$ Nirvana $=$ Night

Music $=$ Brahma $=$ Twilight

Poetic art = Samsara = Day" $($ quoted by NATTIEZ 1997, p. 156)

Tristan waits to meet Isolde till she has put out the torch; their love may live only in darkness. In daylight they have to play their social roles, they have to occupy different positions in the social order of the court, while in darkness they may be finally one, even if not necessarily in concrete sexual intercourse (for all we know, Isolde might even be still a virgin at the end of the opera, since in Act II Marke confesses that he did not dare to approach her and according to the libretto there is no intercourse between her and Tristan). Their orgasm is not a physical, a carnal one, but an ideal one, the result of their self-exaltation in thinking of their final melting into each other, of their final embrace in death. Isolde's Liebestod itself is an orgasm she sinks into to the point of losing the way back, of losing the path that would bring her back to life and to reality. But it is a solitary orgasm, since Tristan has already died: it is the result of Isolde's fantasy before her lover's body, of her imagining him still alive.

Far from representing the supreme triumph of true love, as many believe, Tristan und Isolde shows the limits of love, not only because the mutual fusion attained in the nocturnal orgasm is condemned to yield to the prosaic reality of daylight, in which the lovers go back to their official social role. The limits are more formidable and insuperable. However much they long for prolonging their mutual fusion, they do not cease to be two separate individuals. The final union in death is possible only as a mystic fantasy (the mentioned fantasy, in which Isolde sees Tristan still alive, and the one in which Tristan hears the light and greets the blood flowing from his wound as if it were bringing him life instead of death). In a sense, from the point of view of Schopenhauer's philosophy Tristan and Isolde are negative examples: they are unable to renounce to the will to live they become aware of in their orgasm; rather, they get caught in the mechanism of desire, in which they long to stay eternally.

Interestingly, Wagner mentioned the idea of a fusion in love before he had read Schopenhauer. In a letter from January 1854, he wrote to his fried Röckel, almost paraphrasing Feuerbach: "Human being is man and woman, and it is 
through the union of man and woman that human being comes really to being, it is only through love that man as well as women become [...] human beings. [...] In reality, egoism does not cease till the moment in which an 'I' merge with a "you'" (quoted by NATTIEZ 1997, p. 136). According to Wagner, this aspect would have been neglected by Schopenhauer, about whom he wrote in his diary: "He did not give enough attention to the fact that the world is divided in a masculine and a feminine principle" (March $8^{\text {th }} 1872$, quoted by NATTIEZ 1997, p. 186). In a letter to Schopenhauer, which was never sent and was published only posthumously in 1886, Wagner tried to explain to the philosopher that love is "a path that may lead to salvation, to self-consciousness, to the negation of the Will" (quoted by BORTOLOTTO 2003, p. 294). One may doubt whether the thinker would have approved this position.

The only Wagnerian character that appears to be truly Schopenhauerian is Parsifal. His story is the story of a Bildung, in a sense, since it tells us how an innocent fool (der reine Tor) acquires wisdom and knowledge by learning compassion (durch Mitleid wissend). In Act I he is almost fully devoid of this feeling. He kills a swan and does not understand what is wrong with this action. He sees Amfortas' suffering and does not grasp it. When he learns that his mother is dead his reaction is less a feeling of sorrow or sadness, as rather violent anger towards Kundry, who gave him the news. In Act II he kills pitilessly Klingsor's soldiers in order to reach the flower-maidens. It is only through Kundry's kiss that he becomes able to identify with the others: once again sex is seen as the only possible way of exiting from one's own self and of melting into the Other. At the same time, sex is pain. Parsifal's first words after the kiss are: “Amfortas! Die Wunde! Die Wunde!" (Amfortas! The wound! The wound!"), as if the kiss had inflicted him a wound similar to the one inflicted to the Graal's king by Klingsor. Compassion is learnt through a shared experience of suffering. When he tries to still his longing for the mother by kissing Kundry, Parsifal experiences the aches of desire and love and realizes that a similar longing moved Amfortas to seek soothing in Kundry's embrace. Now Parsifal's heart is bleeding like Amfortas' wound:

"I saw the wound bleeding:

now it bleeds in me!

Here - here! 
No, no! It is not the wound.

Flow in streams, my blood, from it!

Here! Here in my heart is the flame!

The longing, the terrible longing

which seizes and grips all my senses!

O torment of love!"

Love gives torment because love is desire and desire cannot ever be really satisfied; it always leaves emptiness, an internal wound. The only remedy is not only to renounce love, but to renounce desire at all. This renunciation cannot be made out of a single gesture, but implies a long process of learning. This is the reason why Parsifal, after having first kissed, then rejected Kundry, leaves for a long journey in which he dedicates his life to serve the others, becoming a wandering knight. When he finally comes back to Montsalvat he is ready to redeem Amfortas and himself ("Erlösung dem Erlöser!" sings mysteriously the choir).

There has been a huge dispute about the presumed Christian character of this opera. Nietzsche was notably among the fiercest opponents to what he considered to be Wagner's Christian drift. Certainly the opera is full of Christian ideas and symbols, starting from the Graal, the Eucharist, the Baptism of Kundry, etc. On the other side, there are many reasons to doubt the Christian content of Parsifal's story (cf. MAGEE 2001, 280 ff.). As many commentators have remarked, the words Jesus or Christ do not even occur once in the whole opera, contrarily to Heiland (savior) or Erlöser (redeemer), which are more generic. While the Graal knights seek redemption in Christian rituals (showing on the other side no sense of Christian charity, since they force Amfortas to celebrate Eucharist even if they know how painful this is for their king), Parsifal teaches that redemption is found not in institutionalized, ritualized religion, but in abnegation and eventually in renunciation to oneself. Nor is he a Christ-like figure: he does not sacrifice himself for universal redemption. His message is not very Christian at all, rather refers to an old Greek saying according to which what provokes the wound can also heal it (ho trósas iásetai), as symbolized by the fact that the very spear that has opened Amfortas' wound also closes it. It is by experiencing the same desire as Amfortas that Parsifal does become able to heal him - and not through prayers or religious meditation. Finally, if we consider the well-known 
scene of Good Friday in Act III, we sense an almost pantheistic feeling of divinization of Nature. It is not that Nature regenerates itself because of the special meaning of Good Friday (also because such regeneration should be expected rather on Easter day), but it is Good Friday itself that gets a different, deeper meaning by being put in the context of the eternal cycle of Nature, since it coincides with Spring. Easter or Pessach, the passage, celebrates precisely the passage from winter to spring, from death to new life - in Nature and in human beings when they become aware of the truth hidden beyond the veil of existence. In a letter to Mathilde Wesendonk of 1858 Wagner wrote the following remarks on animal suffering: "And so if there is any purpose in all this suffering it can only be the awakening of pity in man, who thus takes up the animal's failed existence into himself, and, by perceiving the error of all existence, becomes the redeemer of the world. This interpretation will become clearer to you some day from the third act of Parzival, which takes place on Good Friday morning" (quoted by NEWMAN 1949, p. 702). This has nothing to do with Christian redemption, nor with the Christian vision of life, rather with Buddhism or... with Schopenhauer. So, the opera that allegedly marks Wagner's "conversion" to Christianity reveals itself to be a celebration of the philosophy of Schopenhauer. Wagner manages finally to create a Schopenhauerian work of art at his third attempt, in his last opera - last not only because he died a couple of months after the premiere, but because he had expressed often the intention of stopping composing operas after Parsifal in order to dedicate himself to symphonic music.

The question that remains unanswered is: Does Parsifal, who has now attained wisdom through compassion, redeem just himself or also the others, as Brünnhilde did? True: he heals Amfortas' wound; but releasing the king from pain means not exactly redeeming him. After all the choir sings: "Erlösung dem Erlöser", "redemption for the redeemer". And from a Schopenhauerian point of view, is any other redemption possible but self-redemption? 


\section{References}

BORTOLOTTO, Mario. Wagner l'oscuro. Milano: Adelphi, 2003.

COOKE, Deryck. I Saw the World End. A Study of Wagner's Ring. Oxford: Oxford University Press, 1979.

KITCHER, Philip; SCHACHT, Richard. Finding an Ending. Reflections on Wagner's "Ring”. Oxford: Oxford University Press, 2004.

MAGEE, Bryan. Aspects of Wagner. Oxford: Oxford University Press, 1988.

MAGEE, Bryan. The Tristan Chord. Wagner and Philosophy. New York: Metropolitan Books, 2001 [ $1^{\text {st }}$ edition: Wagner and Philosophy. London: Penguin, 2000]

NATTIEZ, Jean-Jacques. Wagner androgino. Torino: Einaudi, 1997.

NEWMAN, Ernest. Wagner Nights. New York: Knopf, 1949.

SANS, Edouard. Richard Wagner et la pensée schopenhauerienne. Paris: Klincksieck, 1969.

SCRUTON, Roger. Death-Devoted Heart. Sex and the Sacred in Wagner's "Tristan and Isolde". Oxford: Oxford University Press, 2004.

ŽIŽEK, Slavoj; DOLAR, Mladen. Opera's Second Death. New York; London: Routledge, 2002. 